\title{
Moderating Role of Intrinsic Motivation on the Relationship of Work-Family Conflict and Job Performance in Frontline Officers of Islamic Banks
}

\begin{abstract}
Muhammad K. Riaz ${ }^{1}$, Waseef Jamal ${ }^{2}$, Khawaja Fawad Latif ${ }^{3}$
Abstract

Workplace life hinges on the key aspects of work-family conflict, employee performance and intrinsic motivation. This study explores the boundaries of work-family conflict associated with perceived job performance and the moderating effect of intrinsic motivation on this association amongst the frontline officers of Islamic banks in Pakistan. The exponential rise of Islamic banking over the past decade demands that the exigencies associated with this industry be studied and scrutinized. This study aims to fill this gap in literature on this contemporary issue. The results consistently show that work-family conflict is negatively associated with perceived job performance. Furthermore, intrinsic motivation as moderator, weakens this negative association. The study calls upon the need to properly deploy intrinsic motivation arousing tools to overcome the negative consequences of work-family conflict. It is further suggested that if religious inclinations and obligations are instilled in the organizational ethos, then working in Islamic banks may stimulate the source of intrinsic motivation. The study could provide an overview of the practical implications of work-family conflict to scholars and policy-makers.
\end{abstract}

Key Words: Work-family conflict, perceived job performance, intrinsic motivation, frontline officers, islamic banks.

\section{Introduction}

In today's competitive world, human resources offer the competitive advantage and key to success of any organization (Robbins \& Judge, 2019; 2013, Yavas, Karatepe, Avci, Tekinkus, 2003; Lewis \& Gabrielsen, 1998; LeBlanc \& Nguyen, 1988). One of the aims of organization is to develop high performance work culture and that could

1 PhD Scholar, Institute of Management Sciences, Peshawar $\mathcal{E}$ Lecturer, Department of Management Sciences, COMSATS University Islamabad, Attock Campus. Email: riaz@cuiatk.edu.pk

2 Associate Professor, Institute of Management Sciences, Peshawar

3 Assistant Professor, Department of Management Sciences, COMSATS University Islamabad, Attock Campus

\begin{tabular}{ll} 
ARTICLE HISTORY & \\
11 July, 2018 Submission Received & 18 Nov, 2018 First Review \\
\hline 31 July, 2019 Second Review & 15 Sep, 2019 Third Review \\
\hline 20 Sep, 2019 Accepted &
\end{tabular}


only be achieved with the help of a committed, competent, skilled and result oriented workforce, especially, the frontline employees. Banks are major financial institutions of any country. Human resource working in banking sector is under intense pressure due to recent financial crises, highly competitive banking sector and timing nature of job as mostly the employees stayed on job beyond their working hours. Among those, frontline officers of banks play an integral part in delivering quality services and cultivating a pool of satisfied customers (Karatepe \& Tekinkus, 2006) as they are in direct contact with customers.

Although, importance of frontline officers is recognized, yet they face different problems that arise from the internal and external environments of the bank, these may result in low quality of work and below average job performance. All bank employees in general and frontline officers in particular spend long hours on their job which culminates into stress and exhaustion (Karatepe \& Tekinkus, 2006). As Kamal and Hanif (2009) observe that in Pakistani banks, employee participation in routine decisions is not seen as a driver of their employee performance. This practice brings about feeling of discomfort, burnout and oblivion amongst these employees. Employees perceive that decisions about their common workplace issues taken by managers have significance consequences on their work, family and social lives. Long hours at job, frustration, exhaustion, sense of being ignored and demanding jobs affect the psychological well-being of frontline officers, which consequently ensues into work family conflict. Work family conflict accrues a major negative impact on the job outcomes such as job performance, affective organizational commitment, job satisfaction, and organizational citizenship behaviors (Netemeyer, Brashear-Alejandro \& Boles, 2004; Babakus, Cravens, Johnston \& Moncief, 1999). These impacts cause an increase in turnover intension, actual turnover, absenteeism, and job dissatisfaction. The negative impacts of work family conflict may be reduced by enhancing the level of motivation of employees. Intrinsically motivated employees are innovative and high performing (Miller, 2002). Intrinsic motivation is characterized by motivating nature of the job, growth opportunities and strong commitment to the organization (Bruse, 2003; Deci \& Rayn, 1985; Deci, 1975). Therefore intrinsic motivation may moderate the association of work family conflict with job performance.

Islamic banks are established to provide financial services to the customers demanding satisfaction of the financial needs of Muslims, compliant to their Islamic beliefs, urges and obligations. Al-Ajmi, Abo-Hussain and Al-Saleh (2009) conclude that Islamic beliefs and being ethically, socially responsible Muslim are two key factors that determine banks (Islamic) selection decisions by customers. Al-Wehabie (2011, p.236) is his doctoral study on motivation in Islamic banks; find that most of the employees also commit to their jobs in Islamic banks to satisfy their religious urges. 
They are intrinsically motivated by attaining inner satisfaction and convinced that their job in Islamic financial sector is fulfilling their religious duty. Furthermore, Islamic beliefs and values are significantly motivating them for their jobs (Sulaiman, Ahmad, Sbaih, \& Kamil, 2014; Fontaine \& Ahmad, 2013). Similarly, employees in Islamic banks of Pakistan perceive that Islamic banking is in accordance with Shari'ah and Islamic principles (Shah, Niazi \& Majid, 2016). Therefore, their intrinsic motivation is of immense importance while studying their behaviors in organizational settings. Frontline officer, in the same way, may feel that although they are paid for their jobs, they are simultaneously fulfilling their religious duties and responsibilities.

Accordingly, this study aims to find the effects of work family conflict on job performance as well as to find that whether intrinsic motivation moderates the relationship between work family conflict and job performance. To attain these objectives, remainder of the paper is constructed in the way that in following section, literature is reviewed for hypotheses development. Section three elucidates the methodology to investigate the phenomena under study. In succeeding sections data analysis is carried out, results are reported, discussed and concluded for hypotheses-testing. In the last section, managerial implications, limitations and future directions are also debated.

\section{Literature Review}

\subsection{Work family conflict and job performance}

The changing work environment and family obligations are affecting the employees' psychological wellbeing; consequently, they are facing many issues. One of them is work family conflict - WFC (Poggesi, Mari, \& De-Vita, 2019; Liao, Lau, Hui \& Kong, 2019; Eckart, \& Ziomek-Daigle, 2019). Due to many changes in the working environment, increase ICT usage, and changes in nature of business; researchers of organizational behaviors have started studying WFC from different dimensions and in different contexts (Zhao, Zhang, Kraimer, \& Yang, 2019). WFC "occurs when demands from work and family domains are incompatible, impeding domain performance" (French, Dumani, Allen, \& Shockley, 2018, p. 286). Greenhaus and Beutell (1985) define WFC as the stress created by different demands from work and family domains, where the stress from both work and family domains are incompatible in some regard (Adepoju, 2017). Work and family are two main domains of one's life. In each domain, as per Social Role Theory (SRT; Katz \& Kahn, 1978), employee faces conflicting expectations which may result mostly in conflict. Work obligations may hamper family life and similarly family problems may induce stress and conflict at workplace (Ahmad \& Skitmore, 2003). Thus, WFC is a type of inter-role conflict because both roles of an employee (i.e. being an employee and a family member) demands incompatible and incongruent obligations (Adepoju, 2017). 
Some of the researchers (e.g. Gutek, Searle \& Klepa, 1991) argue that conflict at work and family is bi-directional. Conflict at work will induce conflict at family and vice versa. But empirical evidence does not support this assertion rather the argument of the Greenhaus and Beutell (1985) holds ground that there are two distinct types i.e. work family conflict - WFC or work interfering with family - WIF conflict, and family work conflict - FWC, family interfering with work - FIW conflict (Page, Deuling, Mazzala \& Rospenda, 2018). WFC transpire when energy, time or behavioral demands of the work role conflicts with those of the family roles (Kossek $\&$ Lee, 2017) while FWC occur when the obligations of family life is found irreconcilable with work demands (Greenhaus \& Beutell, 1985). This study is investigating WFC or WIF conflict only.

When job is demanding in nature, requires more time, and efforts, then a strain is developed by the interference of job demands with disposing off family responsibilities (Karatepe \& Tekinkus, 2006; Netemeyer, Boles, \& McMurrian, 1996). This strain is exhibited in the form anxiety, depression and lack of concentration (Pleck, 1977 cited in Khalid, 2017). Generally, when there is emotional exhaustion, employee faces feeling of fatigue, loss of trust and concern, and frustration (Gaines \& Jermier, 1983 cited in Karatepe \& Tekinkus, 2006). Consequently, other employees in general and frontline officers in specific, start perceiving conflict between demands and responsibilities of job, and family / social commitments (Hyman, Baldry, Scholarios $\&$ Bunzel, 2003). This shows that emotional exhaustion is an antecedent of WFC.

Two of the consequences of WFC are role ambiguity and role conflict (Janasz \& Benson, 2007). In their review article, Allen, Herst, Bruk and Sutton (2000) conclude that WFC may affect the work related outcomes (like job satisfaction, organizational commitment, intentions to quit, abseentism, job performance), non-work related outcomes (for example life, marital and family satisfaction) and stress related outcomes (such as general psychological strain, depression, burnout, and work related stress). Emotional exhaustion - EE is one of the three components of burnout (Maslach, \& Leiter, 2016) and is the antecedent of WFC while burnout as a whole is an outcome of WFC. These findings point to a unique relation among emotional exhaustion, burnout and WFC i.e. EE has double effects; it develops WFC as well as burnout, but burnout is the consequence of WFC as well which means the burnout as a consequence of WFC will be more intense and detrimental. Burnout is positively related to WFC (Taylor, Huml \& Dixon, 2019) and depressive symptoms (Kan, \& Yu, 2016). Alam, Biswas and Hassan (2009) also find that WFC has negative impacts on the job performance of the employees as it causes poor job performance leading to turnover intentions. Karatepe and Tekinkus (2006) argue that frontline officers' family, social, and work demands are too conflicting and diverse; resultantly, develop 
conflict which ultimately decreases their performance level. On the basis of above discussion, it is postulated that the WFC has a significant negative effect on the employees' job performance of the Islamic bank frontline officer. Therefore following hypothesis is formulated;

H1: WFC will have a negative relationship with frontline Islamic Bank officers' job performance.

\subsection{Intrinsic motivation and job performance}

Motivated human resource is a prerequisite of enhanced organizational performance and pleasant workplace (Robins \& Judge, 2013; 2019). Motivation has to be harvested in human capital of the organization. Motivating the employees is the most challenging and demanding part of a manager's job. Manager could not achieve their targets, goals and objectives sans motivated team (Cerasoli, Nicklin \& Ford, 2014). This is a continuous function of any manager to search ways, tools, and techniques to engage his team enthusiastically in his efforts for achieving organizational goals. The manager has to build the morale of team and to motivate them for performing at par (Bruse, 2003). Batrol and Martin (1998, p. 381) define motivation as "a force which energizes the behaviors, gives direction to behaviors and underlies the tendency to persist". Self Determination Theory (SDT; Deci \& Ryan, 1985) advocates that motivation is of two types, namely, extrinsic and intrinsic motivation. Extrinsic motivation is attributed to motivation by providing material and monetary incentives (Bruse, 2003) while in intrinsic motivation, recognition for achievement, the job itself, growth and development opportunities are used as motivating tools (Dimitris, 2007; Herzberg, 1968; 2003).

Different researchers (for example Kuvaas, Buch, Weibel, Dysvik \& Nerstad, 2017; Pink, 2011) debate the issue that which one is of more importance. Economists argue that people respond to incentives (tangible mostly), ipso facto according to them, extrinsically motivated employees performed better (Lazear, 2000; Gibbins, 1997). On the other hand, psychologists, sociologists, and HR experts opine that intrinsic motivation play key role in most of our social and economic interactions and transactions (Deci, 1975; Deci \& Ryan, 1985). Amabile (1993) argues that the perception of the task and reasons for engaging in that are the two bases for determining the work motivation as extrinsic or intrinsic. She argues that if employees pursue enjoyment, interest, satisfaction of curiosity, self-expression, or personal challenge in the work, they are intrinsically motivated. On contrary, if they are engaged for achieving some goal apart from the work, then they are extrinsically motivated (p.189). In a recent article (Amabile, 2019) recapitulate the impacts of her work related to intrinsic motivation

and she find it very promising. Reconciling both views, Bénabou and Tirole (2003) 
concludes that both are necessary and not mutually exclusive rather overlapping. These may positively reinforce each other if use properly and timely. Nevertheless, many researchers are of the view that intrinsic motivation, being intra-psychic in nature, is more important in behavioral organizational phenomena. According to Bruse (2003):

People talk about motivation being either intrinsic or extrinsic. But it's really only intrinsic' within each of us. What we refer to as extrinsic motivation is really just external factors, like company perks, bonuses, and pay rises that ultimately affect our intrinsic motivation. (p. 21)

Florida (2004) conducted a study about IT employees' motivation. He asked more than 20,000 employees the question "what matters most to you about your job?" They were asked to select among 38 different factors. Surprisingly, he found that money (an extrinsic motivation) is ranked only fourth, all of the other ten highly valued job factors were intrinsic.

On the basis of the literature reviewed here, it may be concluded that motivation is key to activate an individual to perform a job up to standards. Although, it is evident from the Deci (1975) comments that intrinsic and extrinsic rewards are interacting and interchanging in nature, i.e. a change in one brings change in other form of motivation. But on the basis of other researchers (for example Cerasoli, Nicklin \& Nassrelgrgawi, 2016; Bruse, 2003), it may also be concluded that the intrinsic motivation is the core of motivation for extracting the best performance of an individual and is more important than the extrinsic motivation. Empirical evidence reveals that salespersons' intrinsic motivation has a significant positive effect on their perceptions of performance (Karatepe \& Tekinkus, 2006; Deci \& Ryan, 2008; 2000).

WFC has so many negative affective outcomes (see Section 2.1), therefore, organization always look to find ways for minimizing these effects. Similarly, WFC and job performance have negative relationship as we also hypothesized. This relationship may be moderated by intrinsic motivation because (i) intrinsic motivation is characterized by a good feel for organization (ii) being highly motivated intrinsically, employees exhibited organizational citizenship behaviors - OCBs, (iii) intrinsic motivation has a positive effect on job satisfaction (Low, Cravens, Grant \& Moncief, 2001); Netemeyer et al., 2004), and satisfied employees try to develop a helping, collaborative, supportive workplace, and (iv) in this case of frontline officers of Islamic banks, Islamic religious values are intrinsically motivating them, thus they try to perform better (Karatepe $\&$ Tekinkus, 2006). Therefore it is hypothesized that

H2: Intrinsic motivation will moderate the negative relationship of WFC with job performance such that relationship will be weaken when intrinsic motivation is high. 


\section{Research Methodology}

This explanatory, co-relational, cross sectional study was carried out in the twin cities of Islamabad and Rawalpindi and their vicinities. There are 109 branches of Islamic Banks in twin cities (State Bank of Pakistan, 2016). Frontline officers of the Islamic banks of these two cities are taken as target population. With the help of online branch search, list of all Islamic banks' 109 branches was prepared and then 250 questionnaires were administered at those branches utilizing convenience sampling. A total of 216 questionnaires were returned ( $86.4 \%$ response rate). After the examination of questionnaires 211 questionnaires were found fit for analysis as five of them were not properly filled or were incomplete.

\subsection{Instruments}

The questionnaire comprised of four sections along with a cover letter. In the first section, demographic questions about age, gender, education, marital status, number of children, experience were asked. The Second section was related to WFC while the third and fourth sections items related to intrinsic motivation and perceived job performance were included respectively.

\subsubsection{Work family conflict}

The construct for WFC was developed originally by Burke, Weir, and DuWorse (1979) having eight items. Karatepe and Tekinkus (2006) altered it for their study of frontline bank officers in Turkey. Using Confirmatory Factor Analysis - CFA, they dropped one item from the construct. They used pair-wise CFAs for ensuring discriminant validity. Our study adopted that modified scale which has seven 5 -points $(1=$ strongly negative impact to $5=$ strongly positive impact) Likert scale items. The Cronbach Alpha was .86 in this study (Cronbach, 1951) while composite reliability value was .86 .

\subsubsection{Intrinsic motivation}

The scale developed by Low et al., (2001) for measuring intrinsic motivation of the frontline employees (sales persons) was adopted. It contains 4 items on a 5-points ( $1=$ Strongly disagree to $5=$ Strongly agree) Likert scale. The Cronbach Alpha was 87 for the construct in this study (Cronbach, 1951) while composite reliability value was .82.

\subsubsection{Job performance}

For perceived job performance, a scale developed by Babin and Boles (1998) was adopted. The construct aims to measure subjectively the job performance of employees in a service environment. It has five 5-points ( $1=$ Strongly disagree to $5=$ Strongly 
agree) Likert scale items. The Cronbach Alpha was .83 for the construct in this study (Cronbach, 1951) while composite reliability value was .80.

\subsection{Psychometrics of the instruments}

The adopted scales were analysed through CFA and factor loading using AMOS 22.0 and SPSS 22.0 for dimensionality and convergent validity. Standardized loading are reported in Table 01 ranged from .57 to .82 and t values ranged from 9.33 to 18.42 were significant. One item in WFC scale and one item in perceived job performance scale were dropped due to low loading i.e. .50 and .051 . the rest were above .60 . Results of CFA showed a moderate fit for the three factors model to the data (GFI $=.91$;FI $=.89$; CFI $=.91 ;$ RMSEA $=.0551 ;$ SRMR $=.061)$. The values of AVE were found $>.5$ which ensured the convergent validity of the scales (Hair, Black, Balin, \& Anderson, 2010). The absolute index (i.e. GFI) value is .91 which is acceptable (Miles \& Shevlin, 1998; Bentler \& Bonnet, 1980). Correspondingly, incremental fit indices (NFI and CFI) are around .90 and hence acceptable (Hooper, Coughlan \& Mullen, 2008), although $\mathrm{Hu}$ and Bentler (1999) argue that values of these indices shall be $\geq .95$ for best fit model. Loading values magnitude and model fit indices' values offered support that scales have convergent validity (Anderson \& Gerbin, 1988). Square roots values of constructs' AVE are .72, .73 and .71 which are greater than the inter-construct correlations, hence the discriminant validity of the construct is established (Fonrnell \& Larcher, 1981).

\section{Results}

Descriptive statistics were used for demographics while for main analysis, tools of inferential statistics such as Spearman correlation matrix (Bonett \& Wright, 2000) as there were some ranked variables; and stepwise regression analysis (Lewis, 2007) using SPSS 22.0 were utilized.

\subsection{Demographics}

Table 1: Demographics

\begin{tabular}{|c|c|c|}
\hline Variable & Category & Percentage \\
\hline Gender & & \\
\hline & Male & $90 \%$ \\
\hline & Female & $10 \%$ \\
\hline
\end{tabular}




\begin{tabular}{|c|c|c|}
\hline Age & & \\
\hline & 20-30 Years & $85 \%$ \\
\hline & 31-40 Years & $15 \%$ \\
\hline \multicolumn{3}{|l|}{ Education } \\
\hline & Masters (16 Years) & $55 \%$ \\
\hline & Bachelors (14 Years) & $45 \%$ \\
\hline \multicolumn{3}{|l|}{ Marital Status } \\
\hline & Married & $77 \%$ \\
\hline & Single & $33 \%$ \\
\hline \multicolumn{3}{|l|}{ Experience } \\
\hline & Less than 2 Years & $5 \%$ \\
\hline & 2-5 Years & $77 \%$ \\
\hline & 6-10 Years & $18 \%$ \\
\hline
\end{tabular}

Table 2: Scale Items, Factor Loadings, AVE, Cronbach and Composite Reliabilities $(n=211)$

\begin{tabular}{|c|c|c|c|c|c|}
\hline Scale Items* & $\begin{array}{l}\text { Standardized } \\
\text { loadings }\end{array}$ & $\begin{array}{l}\text { T val- } \\
\text { ues }^{\star *}\end{array}$ & $\begin{array}{c}\alpha \text { Val- } \\
\text { ues }\end{array}$ & AVE & CR \\
\hline \multicolumn{6}{|l|}{ Work family conflict } \\
\hline Person relationship with friends & .59 & 11.82 & \multirow[t]{6}{*}{.86} & \multirow[t]{6}{*}{.51} & \multirow[t]{6}{*}{.86} \\
\hline Mental and physical state at home & .80 & 18.42 & & & \\
\hline Your participation in home activities & .82 & 18.20 & & & \\
\hline Your weekend, vacation time, and social life & .74 & 15.22 & & & \\
\hline Concern for your health or safety & .68 & 14.17 & & & \\
\hline Your personal development & .64 & 13.00 & & & \\
\hline \multicolumn{6}{|l|}{ Intrinsic Motivation } \\
\hline $\begin{array}{l}\text { When I do work well, it gives me a feeling of } \\
\text { Accomplishment }\end{array}$ & .69 & 13.75 & \multirow[t]{5}{*}{.87} & \multirow[t]{5}{*}{.53} & \multirow[t]{5}{*}{.82} \\
\hline \multicolumn{3}{|l|}{$\begin{array}{l}\text { I feel a great sense of personal satisfaction, } \\
\text { when }\end{array}$} & & & \\
\hline I do my job well & .78 & 16.10 & & & \\
\hline $\begin{array}{l}\text { When I perform my job well, it contributes } \\
\text { to my personal growth and development }\end{array}$ & .71 & 15.13 & & & \\
\hline My job increases my feelings of self-esteem & .74 & 15.17 & & & \\
\hline Perceived Job Performance & & & & & \\
\hline
\end{tabular}




\begin{tabular}{|c|c|c|c|c|c|}
\hline I am a top performer & .71 & 15.34 & .83 & .50 & .80 \\
\cline { 1 - 4 } $\begin{array}{c}\text { I get along better with customers than do } \\
\text { others }\end{array}$ & .74 & 16.11 & & & \\
\cline { 1 - 3 } I know more about services delivered to \\
customers & .57 & 9.33 & & \\
\cline { 1 - 3 } I know what my customer expect & .79 & 17.33 & & \\
\hline
\end{tabular}

${ }^{*}$ Each item of the scales were measured on a five point scales

${ }^{* *}$ All loadings are statistically significant at .01 level or higher

Table 3: Spearman Correlation

\begin{tabular}{|c|c|c|c|c|c|c|c|}
\hline & 1 & 2 & 3 & 4 & 5 & 6 & 7 \\
\hline Age & & & & & & & \\
\hline Gender & $.550^{*}$ & & & & & & \\
\hline Marital Status & .342 & .453 & & & & & \\
\hline No of Children & $.543^{*}$ & $.234^{*}$ & $.331^{*}$ & & & & \\
\hline Work Family Conflict & $.311^{* *}$ & $.341^{*}$ & $.423^{* *}$ & $.213^{*}$ & & & \\
\hline Intrinsic Motivation & $.242^{* *}$ & .345 & $.213^{*}$ & .342 & $.134^{* *}$ & & \\
\hline Job Performance & $.102^{*}$ & .112 & .324 & .321 &. $.211^{* *}$ & $.441^{* *}$ & \\
\hline
\end{tabular}

${ }^{*}$ Correlation is significant at 0.05 level ${ }^{* *}$ Correlation is significant at 0.01 level

Table 4: Stepwise Regression Analysis - Effect of Work-Family Conflict on Job Performance Moderated by Intrinsic Motivation

\begin{tabular}{|c|c|c|c|}
\hline Variables & Step 01 $(\beta$ values $)$ & Step 02 $(\beta$ values $)$ & Step 03 ( $\beta$ values) \\
\hline Age & $-.039^{*}$ & $-.035^{*}$ &. $.036^{*}$ \\
\hline Gender & .021 & .020 & .020 \\
\hline Marital Status & -.012 & -.012 &. .013 \\
\hline No. of Children & $-.043^{*}$ & $-.041^{*}$ & .046 \\
\hline Education & $.042^{*}$ & $.040^{*}$ & $.043^{*}$ \\
\hline Work Experience & $.021^{*}$ & $.020^{*}$ & $.018^{*}$ \\
\hline Work Family Conflict - WFC & & $-.214^{* *}$ & $-.211^{* *}$ \\
\hline Intrinsic Motivation - IM & & $.393^{* * *}$ & $.389^{* * *}$ \\
\hline WFC X IM & & &. $.242^{* *}$ \\
\hline R2 & .029 & .301 & .395 \\
\hline$\triangle R 2$ & & .272 & .094 \\
\hline
\end{tabular}

${ }^{*} \mathrm{p}<.05^{* *} \mathrm{p}<.01^{* * *} \mathrm{p}<.001$ 


\subsection{Correlation and regression analysis}

The Spearman correlation analysis showed that age is significantly correlated with all variables of our concern i.e. WFC (rho $=.361, \mathrm{p}<.01)$, intrinsic motivation $(r h o=.242, \mathrm{p}<.01)$, and job performance $(r h o=.132, \mathrm{p}<.05)$, although, Page et al., (2018) concludes that age has a non-linear correlation with WFC as up to middle age, this relationship is positive and near retirements this correlation decreases (Baltes \& Young, 2007). Gender has a significant relationship with WFC (rho=.341, p<.01) i.e. women has more WFC than men. Powell and Greenhaus (2010) argue that "women tend to experience greater family demands while men tend to experience greater work demands." (Page et al., 2018; Martinengo, Jacob \& Hill, 2010). Marital status is correlated significantly with WFC $(r h o=.432, \mathrm{p}<.01)$ and same is the case of number of children and WFC (rho=213, p<.05). Marriage brings another role in to the life of employee and may demands more time, thus, it is a positively correlated with WFC. As Page et al. (2018) anchoring on Kaufman and Uhlengberg (2000), opine that when an employee becomes a parent, he may less likely to reduce the efforts and resources available to him and thus may have more WFC. Correspondingly, children may increase the time and emotional constraints (Taylor \& Dao, 2003) which may result in more WFC for employees with children.

Step-wise hierarchal regression was carried out in three steps. In the first step, control variables were entered e.g. age, gender, marital status, number of children, education and experience $\left(\mathrm{R}^{2}=.029\right)$. In the second step, WFC and intrinsic motivation were entered, and it was found by looking into $\beta$-value $(\beta=-.214, p<.01)$ of WFC that, as expected and predicted, it has a negative impact on job performance and intrinsic motivation has a positive impact on job performance $(\beta=.393, p<.001$; $\mathrm{R}^{2}=.301, \Delta \mathrm{R}^{2}=.272$ ). In the third step, moderator variable (interaction term of work family conflict $\mathrm{x}$ intrinsic motivation) was entered. It was found that intrinsic motivation has a moderating impact on the relationship of work family conflict and job performance $\left(\beta=. .242, p<.01 ; R^{2}=.395, \Delta R^{2}=.094\right)$. The negative sign of the $\beta$ of the moderator/interaction term is indicating the fact that the intrinsic motivation is weakening the negative relationship between WFC and job performance. Consequently, it may be concluded that intrinsically motivating the employees will lessen the negative effects of WFC on job performance.

Results from correlation along with regression analysis supported hypotheses of this study. In the first hypothesis, it was predicted that WFC has a negative impact on job performance. These two has a negative correlation (rho=-.191, p<.05) and a negative but significant beta value $(\beta=-.214, \mathrm{p}<.01)$. Consequently, the $\mathrm{H} 1$ got support and thus accepted. In the second hypothesis, intrinsic motivation was hypothesized to have a moderating effect on the relationship of WFC and job performance. Step- 
wise regression results reported that $\beta$ value of the moderator (interaction term) is significant and negative $(\beta=-.242, \mathrm{p}<.01)$. Furthermore, the value of $\Delta \mathrm{R}^{2}$ is .094 which is quite good and which implicate that there is moderate level of moderating Consequently $\mathrm{H} 2$ is also supported and accepted.

\section{Discussion and Conclusion}

The study aims to investigate the association of work family conflict with job performance and intrinsic motivation as moderator of this relationship. The results supported both hypotheses of the study i.e. WFC has a negative impact on job performance and intrinsic motivation moderated/ weaken the negative relationship between WFC and job performance. These results are in line with the previous literature (Liao et al., 2019; Alam, Biswas \& Hassan, 2009; Van Steenbergen, Ellemers \& Mooijaart, 2007; Karatepe \& Tekinkus, 2006; Kossek, Colquitt \& Noe, 2001).

The mechanism of negative impact of WFC on job performance may be explained with the help of literature. Karatepe and Tekinkus (2006) find that WFC increase the emotional exhaustion of frontline employees of Turkish banks which subsequently affected their job satisfaction and performance negatively. As frontline employees are having "boundary spanning" positions (Aycan \& Eskin, 2004; Aldrich \& Herker, 1977). In these positions, they have huge workloads and inflexible timings which make it very difficult for them to maintain a balance between their job demands and family commitments. Accordingly, their performance deteriorated (Karatepe, 2013; Karatepe \& Tekinkus, 2006; Low et al., 2001; Boles \& Babin, 1996). But, hampering the family commitments may also induce family work conflict - FWC, and thus, in line with Liao et al., (2019), WFC and FWC may be investigated in one study. Furthermore, it is suggested that in future WFC and family work conflict with job performance and moderators (e.g. intrinsic motivation, social support, $\mathrm{OCBs}$ ) may be studied simultaneously.

It is also found that intrinsic motivation moderated the relationship between WFC and job performance. Intrinsic motivation used to affect positively the cognition of employees (Robbins \& Judge, 2019; 2013) to overcome the negative feelings developed due to WFC. These effects successively in turn lessen the negative impacts of WFC on job performance. On the other hand, intrinsic motivation has been found to have positive effects on job performances (Low et al., 2001; Karatepe \& Tekinkus, 2006). In this way, job performance of intrinsically motivated employees is increased which subsequently lessen the magnitude of negative impacts of WFC on job performance.

Synthesizing the above discussion, it can be concluded that work family conflict has negative impacts on the job performance of frontline officers of the Islamic banks 
in twin cities of Islamabad and Rawalpindi. Furthermore, these negative effects are being moderated by intrinsic motivation.

\section{Managerial Implications, Limitations and Directions for Future Research}

The study found that WFC has a negative relationship with job performance of the frontline officers of Islamic banks and this relationship is being moderated by intrinsic motivation. Frontline officers have a key role in banking sector, who are in direct contact with their customers, so their job performance is of immense important. If they are not performing well, their banks will ultimately incur huge losses. Therefore, they have been to be kept performing as per their targets. This study found that job performance of frontline officers of Islamic banks is affected negatively by WFC and these negative effects can be moderated by intrinsic motivation. Thus now, some managerial implications are put forward as following;

- As customers of Islamic banks are driven by their religious urges and obligations, therefore they have to be dealt accordingly. Frontline officers will do that if they are intrinsically motivated using their indoctrinated feelings that they are not only serving customers but also their religion. As Al- Ajmi et al (2009) concludes that selection of Islamic banks is determined by the level of religious obligations and being socially responsible Muslim. In this way, the job itself will be motivating in nature. Consequently, the training of frontline officers at Pakistani Islamic banks may contain material for the inculcation of this aspect fulfilling their religious obligations and urges. It is also suggested that religiously triggered intrinsic motivation may be studied thoroughly. This will help the Islamic financial institutions to adopt such recruit and selection and other HR policies to hire and retain already intrinsically motivated human resource and thus make it easy to perform well in financial sector.

- As the timing of frontline officers are inflexible, and their jobs are too demanding, therefore, it is imperative to recognize and compensate such efforts through different recognition schemes like employee of the month, quarter, year, appreciation letter, or atleast inviting them on a cup of tea by their managers. These schemes will positively enhance intrinsic motivation and the negative impacts of WFC will be minimized.

- The management has to make the workplace pleasant, cooperative and collaborative by involving the employees by utilizing team development techniques. Talking this line, organizational citizenship behaviors (OCBs) may be nurtured in the workplace to make the WFC affectee frontline officers of the Islamic 
banks to feel relax.

The study has several methodological limitations. Firstly, the study is based on convenience sampling which may result in systematic bias which can be minimized by employing large samples. Secondly, being cross sectional in nature, this study cannot establish causal relationship, therefore, longitudinal studies are needed to establish the causality and to investigate the mechanism. Thirdly, self-reported response may result in social desirability bias which may be addressed by collecting data from multiple sources. Finally, it is also recommended that WFC is a complex social phenomenon, therefore, there is a need to design complex research models with the inclusion of maximum possible variables of interests (for example self-construal, Islamic work ethics, cultural values, religiosity/ spirituality) and test using structural equation modelling (SEM). On other hand, to understand the underlying process, qualitative studies (non-structured interviews, in-depth case studies, critical incidents techniques, diary methods and or combination of some of these) may be designed and conducted.

\section{References}

Adepoju, A. (2017). Exploring the Role of Work-Family Conflict on Job and Life Satisfaction for Salaried and Self-Employed Males and Females: A Social Role Approach. Executive Doctorate in Business Thesis, Georgia State University. Retrieved from https://scholarworks.gsu.edu/bus_admin_diss/86/

Ahmad, S., \& Skitmore, M. (2003). Work-family conflict: A survey of Singaporean workers. Singapore Management Review, 25(1), 35-52.

Al-Ajmi, J. Abo-Hussain, H. \& Al-Saleh, N. (2009). Clients of conventional and Islamic banks in Bahrain: How they choose which bank to patronize. International Journal of Social Economics, 36(11), 1086-1112.

Alam, M. S. Biswas, K. \& Hassan, K. (2009). A test of association between working hour and work family conflict: A glimpse on Dhaka's female white collar professionals. International Journal of Business and Management, 4(5), 27-35.

Aldrich, H., \& Herker, D. (1977). Boundary spanning roles and organization structure. Academy of Management Review, 2(2), 217-230.

Allen, T. D., Herst, D. E., Bruck, C. S., \& Sutton, M. (2000). Consequences associated with work-to-family conflict: A review and agenda for future research. Journal of Occupational Health Psychology, 5(2), $278-308$

Al-Wehabie, A. (2011). Motivation of bank employees and effects of culture in the Islamic banking sector: A case study of Al-Rajhi Bank - KSA. (Doctoral dissertation, The University of Hull, UK. Retrieved from https://hydra.hull.ac.uk/assets/hull:10761a/content

Anderson, J.C. \& Gerbing, D.W. (1988). Structural equation modelling in practice: A review and 
recommended two-step approach. Psychological Bulletin, 103(5), 411-423.

Amabile, T. M. (1993). Motivational synergy: Toward new conceptualizations of intrinsic and extrinsic motivation in the workplace. Human Resource Management Review, 3(3), 185-201.

Amabile, T. M. (2019). Educating leaders who make a difference in the world. Perspectives on Psychological Science, 14(1), 7-11.

Aycan, Z. and Eskin, M. (2004). Relative contribution of childcare, spousal, and organizational support in reducing work-family conflict for males and females: the case of Turkey. Paper presented at the Academy of Management Annual Meeting, New Orleans, LA.

Babakus, E., Cravens, D.W., Johnston, M. \& Moncrief, W.C. (1999). The role of emotional exhaustion in sales force attitude and behavior relationships. Journal of the Academy of Marketing Science, 27(1), 58-70.

Babin, B.J. \& Boles, J.S. (1998).Employee behavior in a service environment: a model and test of potential differences between men and women. Journal of Marketing, 62(2), 77-91.

Baltes, B., \& Young, L.M. (2007). Aging and work/family issues. In G. Adams \& K. Shultz (Eds.), Aging and work in the 21st century (pp. 251-256). Mahwah: Lawrence Erlbaum.

Bartol, K M. \& Martin, D. C. (1998). Management. New York: McGraw Hills.

Bénabou, R. \& Tirole, J. (2003). Intrinsic and extrinsic motivation. The Review of Economic Studies, 70(3), 489-520.

Bentler, P.M. \& Bonnet, D.C. (1980). Significance tests and goodness of fit in the analysis of covariance structures. Psychological Bulletin, 88 (3), 588-606.

Bruse, A. (2003). How to motivate every employee: 24 proven tactics to spark productivity in the workplace. New York: McGraw Hills.

Bonett, D. G., \& Wright, T. A. (2000). Sample size requirements for estimating Pearson, Kendall and Spearman correlations. Psychometrika, 65(1), 23-28.

Burke, R.J., Weir, T. \& DuWors, R.E. Jr (1979). Type A behavior of administrators and wives reports of marital satisfaction and well-being. Journal of Applied Psychology, 64(1), 57-65.

Cerasoli, C. P., Nicklin, J. M., \& Ford, M. T. (2014). Intrinsic motivation and extrinsic incentives jointly predict performance: A 40-years meta-analysis. Psychological Bulletin, 140(4), 980-1008.

Cerasoli, C. P., Nicklin, J. M., \& Nassrelgrgawi, A. S. (2016). Performance, incentives, and needs for autonomy, competence, and relatedness: A meta-analysis. Motivation and Emotion, 40(6), 781-813.

Cronbach, L. J. (1951). Coefficient alpha and the internal structure of tests. Psychometrika, 16(3), 297-334.

Deci, E. (1975). Intrinsic motivation. New York: Plenum Press

Deci, E. L., \& Ryan, A. M. (1985). Intrinsic motivation and self-determination in human behavior. New York: 
Plenum Press.

Deci, E. L., \& Ryan, A. M. (2000). The "what" and "why" of goal pursuits: Human needs and the self-determination of behavior. Psychological Inquiry, 11(4), 227-268.

Deci, E. L., \& Ryan, A. M. (2008). Facilitating optimal motivation and psychological well-being across life's domains. Canadian Psychology, 49(1), 14-23.

Gaines, J. \& Jermier, J.M. (1983). Emotional exhaustion in a high stress organization. Academy of Management Journal, 26(4), 567-586.

Greenhaus, J. H., \& Beutell, N. J. (1985). Sources of conflict between work and family roles. Academy of Management Review, 10(1), 76-88

Gutek, B. A., Searle, S., \& Klepa, L. (1991). Rational versus gender role explanations for work-family conflict. Journal of Applied Psychology, 76(4), 560-568.

Eckart, E. C., \& Ziomek-Daigle, J. (2019). An investigation of the variables that influence female counselors' work-family conflict. Journal of Employment Counseling, 56(2), 50-68.

Florida, R. (2004). The rise of the creative class and how it's transforming work, leisure, community and everyday life (Paperback ed.). New York: Basic Books

French, K.A., Dumani, S., Allen, T.D. \& Shockley, K.M. (2018). A meta-analysis of work-family conflict and social support. Psychological Bulletin, 144(3), 284-314

Fontaine, R., \& Ahmad, K. (2013). Strategic Management from an Islamic perspective: Text and cases. Wiley.

Fornell, C., \& Larcker, D. F. (1981). Structural equation models with unobservable variables and measurement error: Algebra and statistics. Journal of Marketing Research, 18(3), 382-388.

Hair, J. F., Black, W. C., Babin, B. J., \& Anderson, R. E. (2010). Multivariate data analysis (7 ${ }^{\text {th }}$ ed). New Jersey: Prentice Hall

Herzberg, F. (2003). One more time: how do you motivate employees? Harvard Business Review Press (reprinted from 1968).

Hooper, D., Coughlan, J. and Mullen, M. R. (2008). Structural equation modelling: Guidelines for determining model fit. The Electronic Journal of Business Research Methods, 6(1), 53 - 60.

Hu, L.T. and Bentler, P.M. (1999). Cut-off criteria for fit indexes in covariance structure analysis: Conventional criteria versus new alternatives, Structural Equation Modeling, 6(1), 1-55.

Hyman, J., Baldry, C., Scholarios, D. \& Bunzel, D. (2003). Work-life imbalance in call centres and software development. British Journal of Industrial Relations, 41(2), 215-239.

Janasz, S. \& Benson, S. (2007). Cognitive capacity for processing work family conflict: An initial examination. Career Development International, 12(4), 397-411 
Kamal, Y. \& Hanif, F. (2009). Pay and job satisfaction: A comparative analysis of different Pakistani commercial banks, MPRA Paper No. 16059, Retrieved from https://mpra.ub.uni-muenchen.de/16059/1/ MPRA_paper_16059.pdf

Katz, D., \& Kahn, R. L. (1978). The social psychology of organizations. New York: Wiley.

Karatepe, O. M. (2013). The effects of work overload and work-family conflict on job embeddedness and job performance: The mediation of emotional exhaustion. International Journal of Contemporary Hospitality Management, 25(4), 614-634.

Karatepe, M. O. \& Tekinkus, M. (2006). The effects of work-family conflict, emotional exhaustion, and intrinsic motivation on job performance of front-line officers. International Journal of Bank Marketing, 24(3), 173-193.

Khalid, U. (2017). Work family conflict/family work conflict: A study of gender and family systems. Pakistan Business Review, 19(2), 481-498.

Kan, D., \& Yu, X. (2016). Occupational stress, work-family conflict and depressive symptoms among Chinese bank employees: The role of psychological capital. International Journal of Environmental Research and Public Health, 13(1), 134-144

Kaufman, G., \& Uhlenberg, P. (2000). The influence of parenthood on the work effort of married men and women. Social Forces, 78(3), 931-947.

Kossek, E. E. \& Lee, K. (Oct. 2017). Work-Family Conflict and Work-Life Conflict. Oxford Research Encyclopaedia of Business and Management. Retrieved from https://doi.org/10.1093/acrefore/9780190224851.013.52

Kuvaas, B., Buch, R., Weibel, A., Dysvik, A., \& Nerstad, C. G. (2017). Do intrinsic and extrinsic motivation relate differently to employee outcomes? Journal of Economic Psychology, 61, 244-258

Lazear, E. (2000). Performance, pay and productivity. American Economic Review, 90(5), 1346-1361.

LeBlanc, G. \& Nguyen, N. (1988). Customers' perceptions of service quality in financial institutions. International Journal of Bank Marketing, 6(4), 7-18.

Lewis, B.R. \& Gabrielsen, G.O.S. (1998). Intra-organizational aspects of service quality management: The employees' perspective. The Service Industries Journal, 18(2), 64-89.

Lewis, M. (2007). Stepwise versus hierarchical regression: Pros and cons. Paper presented at the Annual Meeting of the Southwest Educational Research Association, February 7, 2007, San Antonio.

Liao, E. Y., Lau, V. P., Hui, R. T. Y., \& Kong, K. H. (2019). A resource-based perspective on work-family conflict: meta-analytical findings. Career Development International, 24(1), 37-73.

Low, G. S., Cravens, D. W., Grant, K. \& Moncrief, W. C. (2001). Antecedents and consequences of salesperson burnout. European Journal of Marketing, 35(5/6), 587-611. 
Martinengo, G., Jacob, J. I., \& Hill, E. J. (2010). Gender and the work-family interface: Exploring differences across the family life course. Journal of Family Issues, 31(10), 1363-1390.

Maslach, C., \& Leiter, M. P. (2016). Burnout. In Stress: Concepts, Cognition, Emotion, and Behavior (pp. 351-357). Academic Press.

Miller, J. F. (2002). Motivating people. Executive Excellence, December, p. 15.

Netemeyer, R. G., Boles, J.S. \& McMurrian, R. (1996). Development and validation of work-family conflict and family-work conflict scales. Journal of Applied Psychology, 81(4), 400-410.

Netemeyer, R. G., Brashear-Alejandro, T. \& Boles, J.S. (2004). A cross-national model of job-related outcomes of work role and family role variables: a retail sales context. Journal of the Academy of Marketing Science, 32(1), 49-60.

Robbins, S. P., \& Judge, T. A. (2019). Organizational behavior (18 ${ }^{\text {th }}$ ed). Pearson Publishers.

Robbins, S. P., \& Judge, T. A. (2013). Organizational behavior (15 th ed). Pearson Publishers.

Page, K. J., Deuling, J. K., Mazzola, J. J., \& Rospenda, K. M. (2018). A fresh look at socio-demographics in work-family conflict: A cluster analysis approach. Occupational Health Science, 2(2), 181-201.

Pink, D. H. (2011). Drive: The surprising truth about what motivates us. Penguin.

Pleck, J. H. (1977). The work-family role system. Social Problems, 24(4), 417-427.

Poggesi, S., Mari, M., \& De Vita, L. (2019). Women entrepreneurs and work-family conflict: an analysis of the antecedents. International Entrepreneurship and Management Journal, 15(2), 431-454.

Powell, G. N., \& Greenhaus, J. H. (2010). Sex, gender, and decisions at the family work interface. Journal of Management, 36(4), 1011-1039.

Shah, B. A., Niazi, G. S. K., \& Majid, A. (2016). Employees' Perceptions about Islamic Banking and its Growth Potential in Pakistan. Business E Economic Review, 8(1), 53-76.

Shevlin, M., \& Miles, J. N. (1998). Effects of sample size, model specification and factor loadings on the GFI in confirmatory factor analysis. Personality and Individual Differences, 25(1), 85-90.

State Bank of Pakistan (2016). Appendix-III (a): Distribution of Islamic Banks (Full Fledged Islamic) Branches by cities. Retrieved from http://www.sbp.org.pk/publications/schedule_banks/Dec-2016/Appendices.pdf

Sulaiman, M., Ahmad, K., Sbaih, B., \& Kamil, M, N. (2014). The perspective of Muslim employees towards motivation and career success. Journal of Social Sciences and Humanities, 9(1), 45-62.

Taylor, B., \& Dao, C. (2003). What kids really want that money can't buy. New York: Warner Books.

Taylor, E. A., Huml, M. R., \& Dixon, M. A. (2019). Workaholism in sport: A mediated model of workfamily conflict and burnout. Journal of Sport Management, 33(4), 249-260 
Van Steenbergen, E. F., Ellemers, N. \&Mooijaart, A. (2007). How work and family can facilitate each other: distinct types of work-family facilitation and outcomes for women and men. Journal of Occupational Health Psychology, 12(3), 279-300.

Yavas, U., Karatepe, O. M., Avci, T. \& Tekinkus, M. (2003). Antecedents and outcomes of service recovery performance: an empirical study of frontline employees in Turkish banks. International Journal of Bank Marketing, 21(5), 255-265

Zhao, K., Zhang, M., Kraimer, M. L., \& Yang, B. (2019). Source Attribution Matters: Mediation and Moderation Effects in The Relationship Between Workltolfamily Conflict and Job Satisfaction. Journal of Organizational Behavior. 40(4), 492-505. 